九州大学学術情報リポジトリ

Kyushu University Institutional Repository

\title{
Surface Area Modification of Natural Zeolite Through NaCl Counterbalanced Treatment to Apply in Adsorption Heat Storage System
}

Djubaedah, Euis

Department of Mechanical Engineering, Universitas Indonesia

Wulandari, Arum, Dyah

Department of Mechanical Engineering, Universitas Indonesia

Nasrudd in

Department of Mechanical Engineering, G.L. Bajaj Institute of Technology and Management

Krisnandi, K., Yuni

Departement of Chemistry, Universitas Indoensia

https://doi.org/10.5109/2740938

出版情報: Evergreen. 7 (1)，pp.26-31，2020-03. 九州大学グリーンテクノロジー研究教育センター バージョン:

権利関係 : 


\title{
Surface Area Modification of Natural Zeolite Through NaCl Counterbalanced Treatment to Apply in Adsorption Heat Storage System
}

\author{
Euis Djubaedah ${ }^{1}$, Dyah Arum Wulandari ${ }^{1}, \operatorname{Nasruddin}^{1 *}$, Yuni K. Krisnandi ${ }^{2}$ \\ ${ }^{1}$ Department of Mechanical Engineering, Universitas Indonesia, Indonesia \\ ${ }^{2}$ Departement of Chemistry, Universitas Indoensia, Indonesia \\ *Author to whom correspondence should be addressed: \\ E-mail: nasruddin@eng.ui.ac.id
}

(Received October 31, 2019; Revised January 23, 2020; accepted February 24, 2020).

\begin{abstract}
The natural zeolite from Blitar deposits, a region of Indonesia were studied by simultaneous surface area and porosity measurement used BET analysis. XRD analysis was performed and the result was the natural zeolite contained mordenite and clinoptilolite and small quantities of quartz. From the pattern is also evident that the treatment doesn't affect the mineralogical structure, patterns are identical. Thermophysical analysis, morphology and $\mathrm{Si} / \mathrm{Al}$ ratio were measured. The surface area increases significantly for natural zeolite after $\mathrm{NaCl}$ counterbalance treatment.
\end{abstract}

Keywords: adsorption; natural zeolite; $\mathrm{NaCl}$ counterbalanced; surface area

\section{Introduction}

Zeolites are microporous aluminosilicate mineral with three-dimensional crystal structure which have large open cavities in a regular arrangement as a cage and channels. The cavities occurred from the structural composition of zeolite $^{1,2)}$. Their frameworks are consisting of $\left(\mathrm{SiO}_{4}\right)^{4-}$ and $\left(\mathrm{AlO}_{4}\right)^{5-}$ tetrahedral, where both can build a secondary building unit consisting of single rings 4-, 6- and 8-, or double rings 4-4,6-6 and 8-8 or branched rings 4-1, 5-1, etc. ${ }^{3)}$. The type of framework structure will determine surface area, pore size, and porosity ${ }^{4}$. Zeolite has several advantages compared to other minerals especially its function as ion exchangers, catalysts and adsorbents. Indonesia's position, which is surrounded by oceans and traversed by a series of volcanic rings, makes Indonesia rich in the potential of natural zeolite minerals ${ }^{5,6}$. Zeolite can be used as a catalyst, ion exchange and as adsorbent ${ }^{6}$. In generally, zeolite minerals have the following chemical formula as follows ${ }^{7}$ :

$$
\mathrm{Mx} / \mathrm{n}\left[\left(\mathrm{AlO}_{2}\right) \mathrm{x}\left(\mathrm{SiO}_{2}\right) \text { y.w } \mathrm{H}_{2} \mathrm{O}\right.
$$

Where:

$M=$ the cation of valence $n$

$\mathrm{w}=$ number of water molecules per unit cell zeolite

$\mathrm{x}$ and $\mathrm{y}=$ total tetrahedral number per unit cell

To overcome the problems of the energy crisis and environmental issues, currently, many researchers developed advanced technologies that are more energyefficient, environmentally friendly and used for renewable energy. Utilization of solar radiation to replace fossil energy plays an important role in efforts to preserve primary energy, prevents pollution and global warming ${ }^{8}$. One of the technologies that utilize solar radiation is Thermal Energy Storage (TES). Thermal energy storage applications are widely used for various purposes, for example in some industries there is often a lot of waste heat leftover from the process that has not been utilized even though the heat energy can be stored as a backup or reused for other process needs. Another example is the use of hot water that comes from solar thermal energy, excess heat during the day can be stored for use at night ${ }^{9-11)}$. In recent years, research about sorption thermal energy storage systems are significantly increase become promise option for energy-efficient technology 12-14). The advantage of adsorption heat storage systems is it has high storage density and can store heat energy for a long time in ambient temperature ${ }^{15,16)}$. In the adsorption process, thermal energy can be stored through three steps ${ }^{12,15)}:$ (1) Regeneration/Charging; (2) Storing/Discharging; (3), Adsorption.

Extensive research has been performed in the literature to study the feasibility of various adsorbent-adsorbate pairs to perform adsorption thermal storage ${ }^{17-19)}$. The known molecular sieves zeolite and silica gel are promising candidates for sorbents with the necessary 
physical properties ${ }^{14,20-22)}$. In theory, silica gel has energy densities of $220 \mathrm{kWh} / \mathrm{m}^{3}$ and zeolite has energy density $188 \mathrm{kWh} / \mathrm{m}^{3}{ }^{23}$. From several of studies that have been carried out, synthetic zeolite is more widely discussed than natural zeolite, perhaps because natural zeolite has many disadvantages including high impurities. The presence of impurities in natural zeolite can cause clogging of the pores of zeolites so it will reduce the adsorption performance.

Although the surface area is not the only parameter to determine the performance of the adsorbent, at least the surface area can be one of the parameters that should be considered in the selection of adsorbents for adsorption heat storage system.

In this study, surface area modification by $\mathrm{NaCl}$ counterbalanced treatment of Indonesian natural zeolite was investigated. The objectives of this paper are determining surface area, pore volume, pore size and the $\mathrm{Si} / \mathrm{Al}$ ratio of natural zeolite after $\mathrm{NaCl}$ counterbalanced treatment.

\section{Materials and Methodology}

\subsection{Material Preparation}

The natural zeolites (NZ) were obtained from BlitarEast Java, a region of Indonesia. All zeolites were first milled to particle size in a range of 80 mesh and washing by deionized water $(1: 3 \mathrm{w} / \mathrm{v})$ under stirring for 3 hours. After washing, zeolites dried in the oven at $150{ }^{\circ} \mathrm{C}$ for 3 hours. The process as mentioned above called activated zeolite. After the activation process, $10 \mathrm{~g}$ of natural zeolite was mixed with $0.5 \mathrm{M} \mathrm{NaCl}$ solution $(10 \mathrm{~g}$ zeolite $/ 100 \mathrm{ml}$ solution) at $80^{\circ} \mathrm{C}$ under stirring for $2 \times 8$ hours. After stirring complete, the mixture decantation and washing by deionized water and then filtered. Keep the zeolites at room temperature until dry. The end of the process is drying the zeolite treated at $80^{\circ} \mathrm{C}-100^{\circ} \mathrm{C}$ in the oven to make sure there is no water content in the zeolite.

\subsection{Material Characterization}

The surface area and porosity of prepared samples were evaluated from the $\mathrm{N} 2$ adsorption-desorption isotherms, as calculated at $-196^{\circ} \mathrm{C}$, in the Micromeritics ASAP 2020 system. Before the study, the samples $(0.10 \mathrm{~g})$ were outgassed at $350{ }^{\circ} \mathrm{C}$ for $12 \mathrm{~h}$. Samples total surface area was determined using the Brunauer-Emmett-Teller (BET) equation ${ }^{24)}$, while the t-plot approach has been used to measure the volume and surface area of micropores ${ }^{25}$. Total pore volume was determined from the adsorbed volume at the maximum relative pressure obtained by the adsorption isotherm $(\mathrm{P} / \mathrm{Po}=0.99)$.

X-ray diffraction (XRD) pattern was performed by PANalytical diffractometer using $\mathrm{Cu} K \alpha$ radiation $(\lambda=1.54060 \AA)$, from $5^{\circ}$ to $90^{\circ}$ in $2 \theta$ degrees. The PANalytical X'pert HighScore Pro software was used for the processing of diffractograms and phase identification in combination with the International Center for Diffraction Data (ICDD) files.

X-Ray Fluorescence (XRF): This is for analyzing the elemental composition of the starting, intermediate and final product. The method employed in this research is the energy-dispersive analysis (ED-XRF).

Scanning Electron Microscopy (SEM) and energy dispersive X-Rays spectroscopy (EDS) study were performed using the JEOL JSM-7100F electron microscope. Prior to the study, in order to improve the electrical conductivity, the samples were coated with gold in a sputter coating method.

Fourier Transform Infrared Spectra (FTIR): The infrared spectra deal with complex organic molecules. Data on the nature of a compound can be derived not only from the frequencies that are present but also by peak shape and strength.

Differential Thermal Analysis/ Thermagravimetrics Analysis (DTA/TGA): The thermal analysis is used to evaluate the phase diagram, measurement of the thermal transition and desorption in different atmospheres. It provides thermal and mass loss information. The thermal analysis (DTA/TGA) was carried out with PAN analytical.

\section{Result and Discussion}

\subsection{BET Result}

The surface area, isotherm adsorption and pore distribution of natural zeolite were determined by the Brunauer-Emmett-Teller (BET) method. Surface area modification of natural zeolite with $\mathrm{NaCl}$ counterbalanced is a very significant change in surface area and pore diameter. Table 1 shows the enhancement of the surface area of the zeolite from $202 \mathrm{~m}^{2} / \mathrm{g}$ becomes $297 \mathrm{~m}^{2} / \mathrm{g}$, but pore size and pore volume decrease.

Table 1. BET result of natural zeolite before and after $\mathrm{NaCl}$ counterbalanced

\begin{tabular}{|c|c|c|c|}
\hline Zeolite & $\begin{array}{c}\text { Surface } \\
\text { Area } \\
\left(\mathrm{m}^{2} / \mathrm{g}\right)\end{array}$ & $\begin{array}{l}\text { Pore } \\
\text { Size } \\
(\mathbf{n m})\end{array}$ & $\begin{array}{c}\text { Pore } \\
\text { Volume } \\
\left(\mathrm{Cm}^{3} / \mathrm{g}\right)\end{array}$ \\
\hline $\begin{array}{l}\text { Natural } \\
\text { Activated }\end{array}$ & 202 & 3.7 & 0.094 \\
\hline $\begin{array}{l}\text { Natural Zeolite }-\mathrm{NaCl} \\
\text { Counterbalanced }\end{array}$ & 297.5 & 2.92 & 0.070 \\
\hline
\end{tabular}

The presence and form of the mesoporous can be inferred by studying the structure of the $\mathrm{N}_{2}$ adsorption and the desorption of the isotherm. Nitrogen adsorption involves the physical interaction of gas molecules with the surface of the sample through the force of van der Waals. $\mathrm{N} 2$ adsorption isotherms of Indonesian natural zeolite. Fig. 1 is compatible with type IV isotherms in the IUPAC classification system for mesoporous materials ${ }^{26}$. 


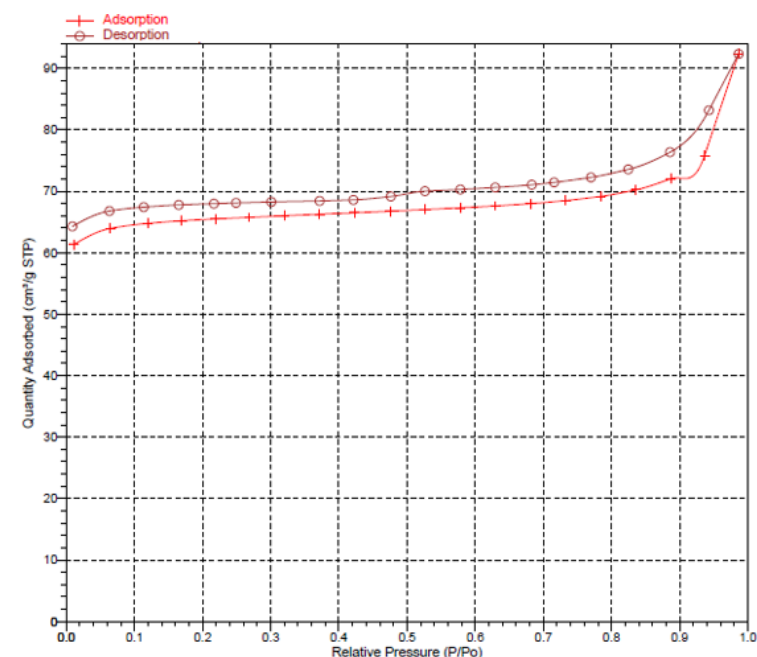

(a) Natural Zeolite before $\mathrm{NaCl}$ counterbalanced

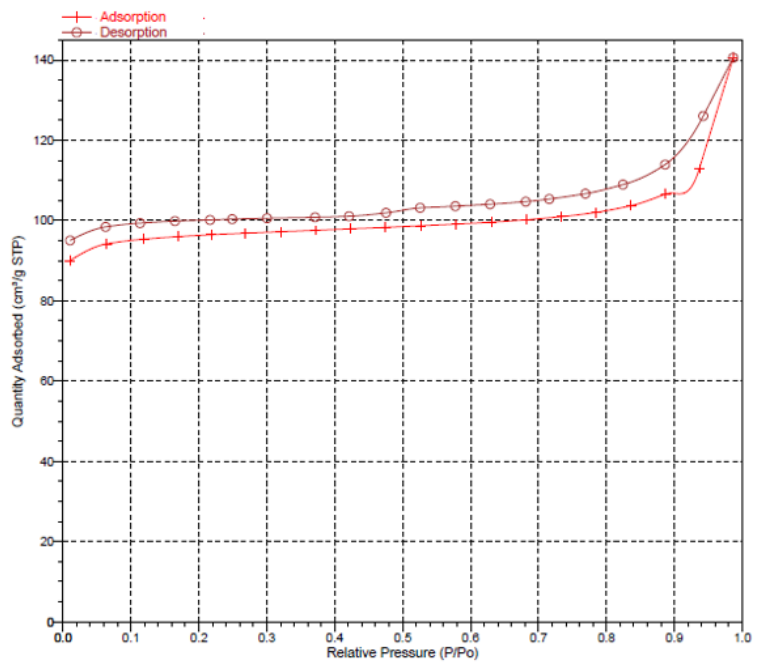

(b) Natural Zeolite after $\mathrm{NaCl}$ counterbalanced

Fig. 1: (a) N2 adsorption of natural zeolite activated before and after treatment by $\mathrm{NaCl}$ counterbalance

\subsection{XRD Result}

Mineralogical analysis of the natural zeolite sample (before and after $\mathrm{NaCl}$ counterbalance) was carried out. The results show in Fig. 2 and Fig. 3 that the natural zeolite formed from mordenite and clinoptilolite and small quantities of quartz. It is also clear from the sequence that the treatment does not change the mineralogical structure, the patterns are the same.

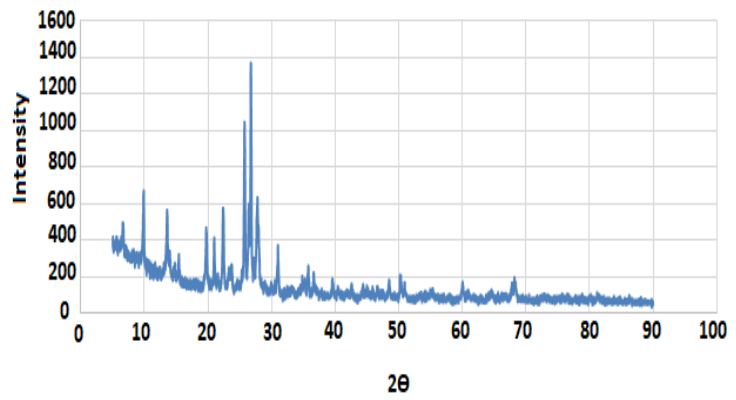

Fig. 2: X-ray Diffraction Pattern for natural zeolite activated

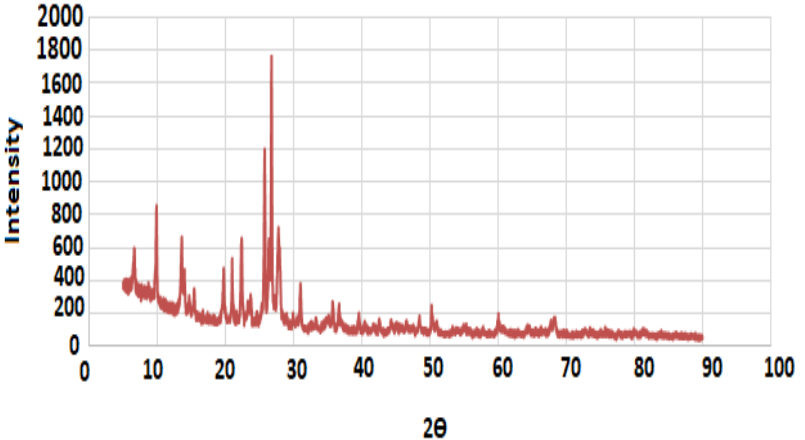

Fig. 3: : X-ray Diffraction Pattern for natural zeolite after $\mathrm{NaCl}$ Counterbalanced

\subsection{XRF Result}

The chemical composition of the zeolite reported by the manufacturer (Zeocem, a.s.) and the findings of the X-ray fluorescence analysis are shown in Table 2.

Table 2. Chemical composition of natural zeolite activated and after $\mathrm{NaCl}$ counterbalance by XRF analysis

\begin{tabular}{|c|c|c|}
\hline Element/ & $\begin{array}{c}\text { NZ-activated } \\
\text { Concentration } \\
(\%)\end{array}$ & $\begin{array}{c}\text { NZ-NaCl } \\
\text { counterbalanced } \\
\text { Concentration } \\
(\%)\end{array}$ \\
\hline $\mathrm{MgO}$ & 7.21 & 7.04 \\
\hline $\mathrm{Al}_{2} \mathrm{O}_{3}$ & 8.36 & 8.51 \\
\hline $\mathrm{SiO}_{2}$ & 64.77 & 69.56 \\
\hline $\mathrm{P}_{2} \mathrm{O}_{5}$ & 0.77 & 0.79 \\
\hline $\mathrm{K}_{2} \mathrm{O}$ & 3.58 & 3.60 \\
\hline $\mathrm{CaO}_{\mathrm{TiO}}$ & 6.64 & 2.75 \\
\hline $\mathrm{MnO}_{2}$ & 0.77 & 0.72 \\
\hline $\mathrm{Fe}_{2} \mathrm{O}_{3}$ & 0.17 & 0.14 \\
\hline
\end{tabular}

\subsection{FTIR Result}

The IR spectrum expresses the amount of infrared radiation transmitted through the frequency of the waves. The specific identity of the zeolite structure is usually drawn from the peaks that appear in wavenumber 1250 $\mathrm{cm}^{-1}-350 \mathrm{~cm}^{-1}$, and the wave number $4000 \mathrm{~cm}^{-1}-1250$ $\mathrm{cm}^{-1}$ is an absorption group that is not a specific identity of the zeolite structure.

FTIR spectrum is shown in Fig. 4 that the presence of water appears at the peaks that occur in the range of 3400 $\mathrm{cm}^{-1}-3600 \mathrm{~cm}^{-1}$ as a result of the stretching of $\mathrm{OH}$ vibrations. The area of the presence of water formed in the natural zeolite counterbalanced by $\mathrm{NaCl}$ is greater compared to natural zeolite activated and raw material. The absorption area is seen in the range of $1600 \mathrm{~cm}^{-1}$ $1700 \mathrm{~cm}^{-1}$. The peak of $1638,15 \mathrm{~cm}^{-1}$ is the presence of Si$\mathrm{O}$ vibrations for natural zeolite counterbalanced by $\mathrm{NaCl}$. It has slightly higher the natural zeolite activated and raw. And areas of $1052 \mathrm{~cm}^{-1}$ is the presence of Al-O vibrations. 


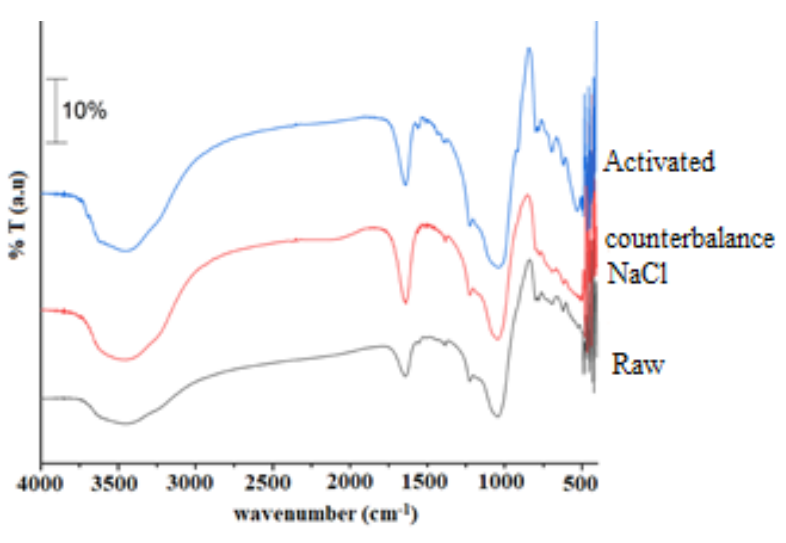

Fig. 4: FTIR spectra of natural zeolite activated before and after treatment by $\mathrm{NaCl}$ counterbalance

\subsection{SEM Result}

The morphologies of natural zeolite samples obtained from SEM analysis are given in Fig 5. And analysis of element composition of natural zeolite was observed by EDS analysis is shown in Table 3.

Table 3. EDS result of natural zeolite before and after treatment

\begin{tabular}{|l|l|l|}
\hline Element & $\begin{array}{c}\text { Natural Zeolite } \\
\text { activated } \\
\text { Mass \% }\end{array}$ & $\begin{array}{c}\text { Natural Zeolite - } \\
\text { Nacl Counterbalanced } \\
\text { Mass \% }\end{array}$ \\
\hline $\mathbf{C}$ & 13.68 & 48.77 \\
\hline $\mathbf{O}$ & 39.78 & 4.19 \\
\hline $\mathbf{N a}$ & 1.16 & - \\
\hline $\mathbf{M g}$ & 0.07 & 6.73 \\
\hline $\mathbf{A l}$ & 4.5 & 37.62 \\
\hline $\mathbf{S i}$ & 26.41 & 0.17 \\
\hline $\mathbf{C l}$ & 0.16 & 0.51 \\
\hline $\mathbf{K}$ & 2.87 & 0.85 \\
\hline $\mathbf{C a}$ & 4.93 & 1.15 \\
\hline Fe & 6.44 & 100 \\
\hline Total & 100 & 5.59 \\
\hline Si/Al & 5.87 & \\
\hline
\end{tabular}

The result of EDS analysis showed that the exchangeable cations in natural zeolite structure were $\mathrm{Na}$ - K - Ca. According to the ion - exchange background of the process, it can be observed the concentration of exchangeable cations ( $\mathrm{Na}, \mathrm{K}$ and $\mathrm{Ca}$ ) after $\mathrm{NaCl}$ counterbalance treatment. $\mathrm{Na}$ cation is increased in concentration after ion exchange, $\mathrm{Na}^{+}$is later expected to be able to carry $\mathrm{H}_{2} \mathrm{O}$ groups, which is interpreted as the potential for $\mathrm{H}_{2} \mathrm{O}$ absorption.

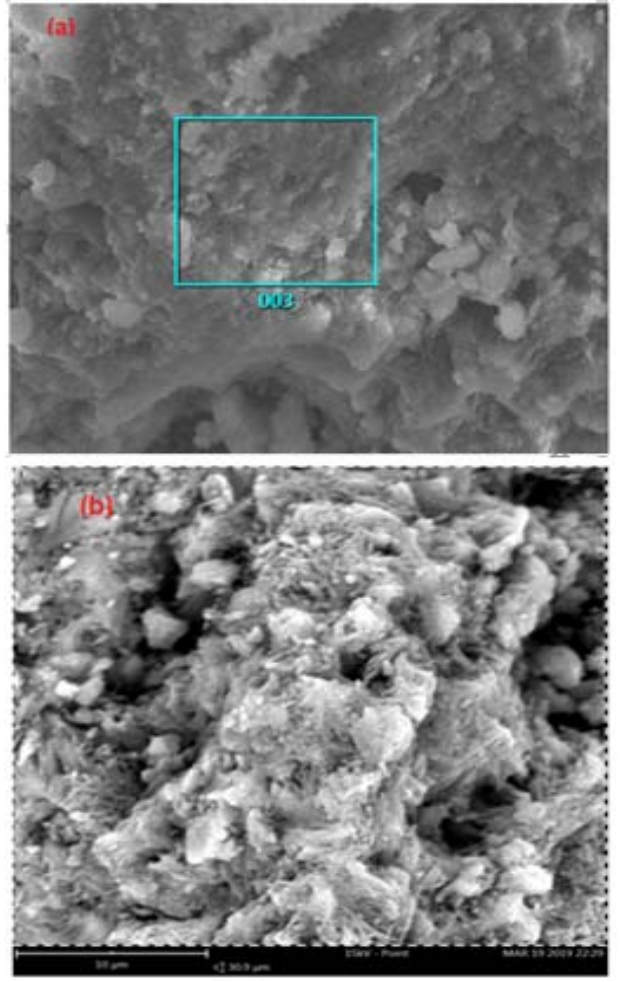

Fig.5 (a): Morphology of natural zeolite activated, (b) Morphology of natural zeolite with $\mathrm{NaCl}$ counterbalanced

\subsection{TGA/DTA Resul}

In the adsorption of thermal energy storage, the regeneration or desorption process is carried out starting from $25^{\circ} \mathrm{C}-200{ }^{\circ} \mathrm{C}$, so it is necessary to analyze the thermal characteristics that occur at that temperature range. Fig. 6 below represents the corresponding sample TGA thermal analysis. The curve in red color stands for the natural zeolite counterbalanced by $\mathrm{NaCl}$, while the one in color blue stands for natural zeolite activated.

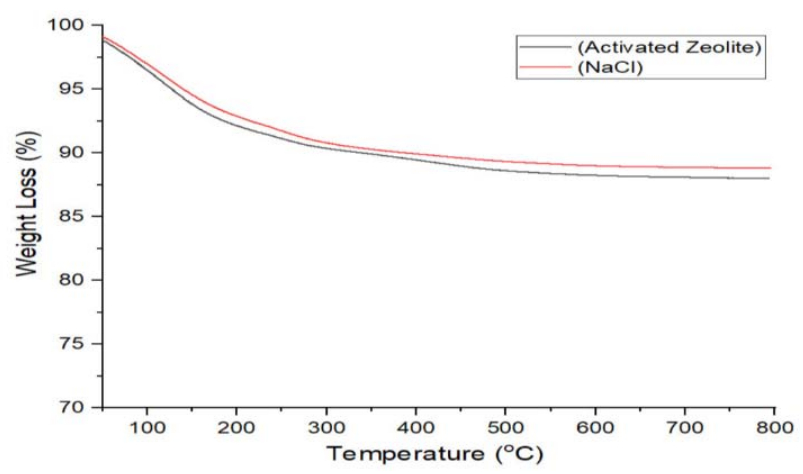

Fig. 6: TGA of natural zeolite before and after treatment

Thermal examination reveals the presence of endothermic effects, common for natural zeolite, which does not cause structural changes and thermal dehydration, under which the natural zeolite under investigation loosens physically and chemically bound water. The 
thermal characteristics of natural zeolite before and after counterbalanced $\mathrm{NaCl}$ have almost the same properties.

\section{Conclusion}

Natural zeolites were successively treated with a $\mathrm{NaCl}$ counterbalance. The effect of $\mathrm{NaCl}$ on the structure has been studied. There are no changes in a mineralogical structure after $\mathrm{NaCl}$ treatment. The $\mathrm{Si} / \mathrm{Al}$ ratio of the zeolite sample decreased slightly. The $\mathrm{NaCl}$ treatment changes the pore structure of the zeolite sample and increases the specific surface area of the sample. The specific surface area of natural zeolites increased from $202 \mathrm{~m}^{2} / \mathrm{g}$ to $297 \mathrm{~m}^{2} / \mathrm{g}$ after being treated with $\mathrm{NaCl}$. Heat treatment at low temperatures has a negligible effect on the pore structure of zeolite samples. Natural zeolite treated with $\mathrm{NaCl}$ has the better potential of water absorption ability compared to other samples, this can be seen from the results of FTIR and EDS analysis.

\section{Acknowledgements}

The authors acknowledge the financing support from Ministry of Research, Technology and Higher Education of the (KEMENRISTEKDIKTI) Republic of Indonesia for Grant Research Doctors (PDD) No. 1/E1/KP.PTNBH/2019 - 234/PKS/R/UI/2019 - NKB1847/UN2.R3.1/HKP.05.00/2019.

\section{References}

1) Coombs, D.S., et al., "Recommended nomenclature for zeolite minerals: report of the subcommittee on zeolites of the International Mineralogical Association, Commission on New Minerals and Mineral Names. Mineralogical Magazine, 1998. 62(4): p. 533-571.

2) Alberti, A., "On the crystal structure of the zeolite heulandite." TMPM Tschermaks Mineralogische und Petrographische Mitteilungen, 1972. 18(2): p. 129-146.

3) Baerlocher, C., L.B. McCusker, and D.H. Olson, Atlas of zeolite framework types. 2007: Elsevier.

4) Tatlier, M., G. Munz, and S.K. Henninger, Relation of water adsorption capacities of zeolites with their structural properties. Microporous and Mesoporous Materials, 2018. 264: p. 70-75.

5) Kusdarto, K., POTENCY OF ZEOLITE IN INDONESIA. Jurnal Zeolit Indonesia, 2008. 7(2): p. 78-87.

6) Dyah Arum Wulandari, N., Euis Djubaedah Thermal Behavior and Characteristic of Pangandaran Natural Zeolite EVERGREEN Joint Journal of Novel Carbon Resource Sciences \& Green Asia Strategy, 2019. 06(03): p. pp225-229.
7) Polatoğlu, İ., Chemical behaviour of clinoptilolite rich natural zeolite in aqueous medium. 2005, Izmir Institute of Technology.

8) Rouf, R.A., et al., Energy management and heat storage for solar adsorption cooling. EVERGREEN Joint Journal of Novel Carbon Resource Sciences \& Green Asia Strategy, 2016. 3(2): p. 1-10.

9) Hasnain, S.M., Review on sustainable thermal energy storage technologies, Part I: heat storage materials and techniques. Energy Conversion and Management, 1998. 39(11): p. 1127-1138.

10) Alva, G., Y. Lin, and G. Fang, An overview of thermal energy storage systems. Energy, 2018. 144: p. 341-378.

11) Fernandes, M.S., et al., Review and future trends of solar adsorption refrigeration systems. Renewable and Sustainable Energy Reviews, 2014. 39: p. 102123.

12) Helaly, H.O., et al., Theoretical and experimental investigation of the performance of adsorption heat storage system. Applied Thermal Engineering, 2019. 147: p. 10-28.

13) Wentworth, W.E. and E. Chen, Simple thermal decomposition reactions for storage of solar thermal energy. Solar Energy, 1976. 18(3): p. 205-214.

14) Tatsidjodoung, P., N. Le Pierrès, and L. Luo, $A$ review of potential materials for thermal energy storage in building applications. Renewable and Sustainable Energy Reviews, 2013. 18: p. 327-349.

15) Ülkü, A.S. and M. Mobedi, Adsorption in Energy Storage, in Energy Storage Systems, B. K1lkış and S. Kakaç, Editors. 1989, Springer Netherlands: Dordrecht. p. 487-507.

16) Aristov, Y.I., Adsorptive transformation and storage of renewable heat: Review of current trends in adsorption dynamics. Renewable Energy, 2017. 110: p. 105-114.

17) Henninger, S.K., et al., New materials for adsorption heat transformation and storage. Renewable Energy, 2017. 110: p. 59-68.

18) Liu, C., et al., Advanced materials for energy storage. Advanced materials, 2010. 22(8): p. E28-E62.

19) Hongois, S., et al., Development and characterisation of a new MgSO4-zeolite composite for long-term thermal energy storage. Solar Energy Materials and Solar Cells, 2011. 95(7): p. 1831-1837.

20) Xu, S.Z., et al., Performance characterizations and thermodynamic analysis of magnesium sulfateimpregnated zeolite $13 X$ and activated alumina composite sorbents for thermal energy storage. Energy, 2019. 167: p. 889-901.

21) Cabeza, L.F., A. Solé, and C. Barreneche, Review on sorption materials and technologies for heat pumps and thermal energy storage. Renewable Energy, 2017. 110: p. 3-39.

22) Xu, S.Z., et al., A zeolite 13X/magnesium sulfatewater sorption thermal energy storage device for 
domestic heating. Energy Conversion and Management, 2018. 171: p. 98-109.

23) $\mathrm{Yu}$, N., R.Z. Wang, and L.W. Wang, Sorption thermal storage for solar energy. Progress in Energy and Combustion Science, 2013. 39(5): p. 489-514.

24) Brunauer, S., P.H. Emmett, and E. Teller, Adsorption of Gases in Multimolecular Layers. Journal of the American Chemical Society, 1938. 60(2): p. 309-319.

25) Lippens, B.C. and J.H. de Boer, Studies on pore systems in catalysts: $V$. The $t$ method. Journal of Catalysis, 1965. 4(3): p. 319-323.

26) Thommes, M., et al., Physisorption of gases, with special reference to the evaluation of surface area and pore size distribution (IUPAC Technical Report). Pure and Applied Chemistry, 2015. 87(9-10): p. 1051-1069. 